6. Особенности женской психологии в трактовке П. Ф. Каптерева. Электронный журнал Эл. Ресурс. Режим доступа «Психологическая наука и образование». www.psyedu.ru / ISSN: 2074-5885 / E-mail: box @ psyedu.ru 2010, № 2 .

\title{
МЕЖЛИЧНОСТНЫЕ ОТНОШЕНИЯ В МНОГОДЕТНОЙ СЕМЬЕ Федотова О.В.
}

К сожалению, в современном российском обществе многодетных семей не так уж много. Согласно статистике, А.И.Антонова, 65\% российских семей имеют одного ребенка, 28\% - двоих, и только 7\% - троих и более [2].

На сегодняшний день, такими исследователями как А.И.Антонов (советский и российский социолог, доктор философских наук, профессор, заведующий кафедрой социологии семьи и демографии социологического факультета МГУ им. М. В. Ломоносова, один из основателей Всемирного конгресса семей (1995)) [17], Л.Л. Баландина (доцент кафедры психологии Пермского государственного педагогического университета, доцент кафедры общей и клинической психологии Пермского государственного университета, кандидат психологических наук) [16], Т. А. Куликова (кандидат педагогических наук, профессор) [13], которые занимаются изучением оптимального количества детей в семье, выявлено, что эффективность воспитания, своевременный запуск механизмов социализации детей, гармония отношений между супругами, снижение конфликтности в отношениях, эмоциональная среда и психологическая атмосфера в семье напрямую зависят от количества детей.

Стоит упомянуть, что российский психолог и организатор науки В. Н. Дружинин занимался изучением психологии семьи. Хоть он и не делал акцент на особенности именно многодетных семей, но, безусловно, при изучении любой отрасли семейной психологии, можно опираться на результаты его исследований, на его научные работы. Плюс ко всему, он в своей работе «Психология семьи» рассматривает различные модели семьи, одна из которых «Общехристианская модель семьи», которая, безусловно необходима для изучения, потому что напрямую касается нашей темы, так как в данной модели речь идёт о многодетных семьях, а не о малодетных или среднедетных [6]. Хотя, в данной работе речь всё же идёт о религиозном воспитании, но религия и есть одно из условий заведения многодетной семьи. Всего их четыре, согласно классификации Т.А. Куликовой: семьи, которые выбрали многодетность сознательно, опираясь на крепкие семейные или религиознонациональные традиции; семьи, в которых родители сознательно не стремились иметь много детей: третий и последующий дети могли появиться в них, главным образом, из-за отсутствия планирования семьи; семьи, которые созданы при рождении общего ребенка при повторном браке отца или матери при наличии других детей; неблагополучные многодетные семьи [7].

Внутрисемейные связи в многодетной семье, как известно, включают супружеские отношения, детско-родительские отношения и отношения между 
детьми. Эти отношения в течение последних десятилетий стремительно менялись, всё большую ценность приобретала эмоционально-психологическая сторона семейно-брачных отношений. Это значительно осложняет семейную жизнь, так как резко повышается уровень ожиданий по отношению к семейной жизни, реализовать который многие супруги не в состоянии в силу культурных традиций общества и индивидуальных особенностей самих супругов. Однако по-прежнему в многодетных семьях создается коллектив, и здесь есть с кого брать пример, за кого отвечать. В такой семье у каждого естественным образом воспитываются чувство товарищества и дружбы, сопереживания, любовь друг к другу и искореняются чувства эгоизма и жадности [9].

В семейных отношениях многодетные родители ценят любовь и заботу друг о друге, взаимное уважение и доверие, семейное единство и сплоченность. Наиболее предпочтительными характеристиками супругов являются умение любить и заботиться о семье и детях, качества хорошего родителя и совпадающие жизненные ценности и установки. В основе семейного образа жизни лежат традиционные ценности рождения и воспитания детей, a доминирующим фактором структуры семейных ценностей являются ценности заботы [11].

Также, стоит отметить, что родители в многодетной семье обычно отличаются сильной психологической устойчивостью. Они более успешно выдерживают стрессы, они могут легко преодолевать жизненные трудности, потому что они уже расставили приоритеты ценностей и сделали свой выбор в пользу самого дорогого - своих детей. Отличительная особенность многодетных родителей в том, что они уверены, что они молодцы. Они усиленно поддерживают родительский статус под давлением общества. Люди, которые заводят большую семью, более сильные в некоторых аспектах, более ответственные, но это не повод для расслабления. Количество детей - это не гарантия по отношению к семье, как это ни печально [4].

Л.И.Савинов указывает, что для родителей многодетных семей чаще присущи следующие ценности супружества:

1) ценность брака;

2) ценность равноправия супругов (ценность доминирования одного из них);

3) ценности различных половых ролей в семье;

4) ценность межличностных коммуникаций между супругами;

5) ценность отношений взаимоподдержки и взаимопонимания супругов [8].

Если брак изначально построен на любви и взаимном доверии, дети только упрочат его и будут приносить родителям радость. Такие семьи становятся только крепче, когда появляются дети. Но на практике не редки случаи, когда большое количество детей превращаются для родителей просто в груз и препятствуют развитию нормальных взаимоотношений между супругами. Часто у родителей за множеством забот просто не остаётся времени и сил поговорить друг с другом [12]. 
Важным вопросом в изучении межличностных отношений родителей и детей в многодетной семье является выявление механизмов взаимодействия, так как они явно отличаются от механизмов взаимодействия в семьях с одним и двумя детьми. Это не линейные единичные, а многомерные связи, которые можно сравнить с такими, которые прослеживаются, например, между сотрудниками в небольшом офисе.

В многодетных семьях характер детско-родительских отношений имеет свою специфику. Отличительными особенностями членов многодетных семей являются большая центрированность на семье, стремление к общесемейному времяпрепровождению, совместным играм, более внимательное отношение друг к другу, уважение к отцу, роль которого в воспитании детей возрастает. У детей из больших семей имеется настоятельная потребность видеть всю семью единой и не включать в неё никого другого.

С увеличением размера семьи меняется характер детско-родительских отношений: постепенно происходит обеднение всех сторон общения, усиливаются авторитаризм, жесткость в воспитании, увеличивается психологическая дистанция. Родители принимают, поддерживают своих детей, разносторонне их характеризуют и, в большей части, положительно [15].

Важным аспектом является по мере взросления ребенка из детскородительских отношений переходить в отношения партнёрские. Если использовать термин, предложенный Э. Берном «партнёрские отношения», который он раскрывает как «отношения типа «взрослый-взрослый»»), можно заметить, что при таком взаимодействии в семье возникает меньше всего проблем по причине того, что детей и родителей изначально объединяют общие интересы, например, проживая на сельской местности, вся семья занимается ведением хозяйства, и даже дети вовлечены в эту работу с раннего возраста. Но, при этом, стоит учитывать то, что сами родители должны быть свободны от Эго-состояния Ребёнка [3].

Некоторые психологи изучают особенности развития ребенка в зависимости от порядка его рождения в семье. Основу такого подхода заложили 3. Фрейд и А. Адлер. 3. Фрейд первым отметил, что позиция ребенка среди его сестер и братьев имеет особое значение для всей его дальнейшей жизни. Эта позиция определяется количеством детей в семье, их полом и промежутками между их рождением. Чем ближе возраст детей, тем большее влияние они оказывают друг на друга в процессе своего развития [10].

А. Адлер, рассматривал порядок рождения как основную детерминанту установок сопутствующую стилю жизни. Он дал описание личностных особенностей первенца (старшего), второго ребенка (среднего), последнего (младшего) и единственного ребенка в семье. По Адлеру, порядок рождения (позиция) ребенка в семье имеет решающее значение. То есть от того, какое значение придает ребенок сложившейся ситуации, зависит, как повлияет порядок его рождения на стиль жизни [1].

На отношения детей между собой огромное значение имеет отношение родителей к детям. Отношение «взрослый-ребенок» выступает определяющим 
фактором в мотивационно-потребностной сфере межличностных отношений между детьми [14].

Важно уточнить такой момент, что могут существовать разные виды отношений между старшими и младшими детьми: старшие могут начать руководить младшими, а могут и стать беспрекословными исполнителями желаний малышей. Кроме того, старший пытается каким-то образом противостоять младшему брату или сестре, которому достается огромная часть родительского внимания.

Первенцы часто исполняют роль суррогатного родителя для своих меньших братьев (сестер) т.е. становятся их опекунами, отсюда их сознательность и уважение к власти. Немаловажной является разница в возрасте между детьми. Считается, что "закладка" основных характеристик личности человека происходит до 6 лет. Поэтому, возможно, что первенец, который старше остальных детей более чем на 6-7 лет, сохранит характеристики единственного ребенка в семье [5].

Приведенные данные позволяют сделать вывод о том, что многодетные семьи отличает ряд особенностей, которые определяют отношения между супругами, родителями и детьми, детьми между собой.

\section{Литература}

1. Adler, A. Social interest. Birth order and personality [Текст] / A. Adler. NewYork: Putnam, 1939.

2. Антонов А. И. Многодетная семья в современном обществе: условия жизни, общественное мнение, меры социальной политики [Текст] / А. И. Антонов. - М.: Наука, 2008.

3. Берн, Э. Трансакционный анализ в психотерапии / пер. с англ. А. Грузберга. - М.: Эксмо, 2009.

4. Бурмистрова Е. «Взаимоотношения супругов в многодетной семье// «Многодетная семья». - 2010. - №19.

5. Давлетова, А. Д. Ориентировка личности в психологическом пространстве родительской семьи [Текст] / А.Д. Давлетова. - М., 2001.

6. Дружинин В. Н. Психология семьи [Текст]: научное издание / В. Н. Дружинин. - 3-е изд. - М.: Питер, 2007.

7. Куликова Т. А. Преимущества многодетной семьи [Текст] / Т. А. Куликова. [электронный ресурс]. - Режим доступа. http://www.ipapa.ru/semya/22-mnogodetniy-papa/207advantage-much-childsfamilies.htm/

8. Савинов, Ј. И. Образ жизни семьи и ценностные установки супругов [Текст] / Л.И. Савинов // Вопросы психологии. - 2008, № 3.

9. Сермягина, О. С. Многодетная семья в современном мире [Текст] / О.С. Сермягина. - М.: Проспект, 2008.

10. Хьелл, Л. А., Зиглер, Д. Дж. Теории личности [Текст] / Л. А. Хьелл, Д. Дж. Зиглер. - СПб.: Питер, 2007.

11. Эйдемиллер, Э. Г. Семейный диагноз и семейная психотерапия [Текст] / Э. Г. Эйдемиллер. - СПб: Речь, 2013. 
12. Гущин И., Феофанов К. Многодетная семья: отношения, условия жизни, воспитание детей [Текст] / Гущин И., Феофанов К. [электронный pecypc]. - Режим доступа. - http://www.7ya.ru/article/mnogodetnye-semi/

13. Куликова Татьяна Абрамовна [Текст] / Издательский центр «Академия» [электронный ресурс]. - Режим доступа. - http://www.academiamoscow.ru/authors/detail/44137/

14. Гаврилова А. Консультация «Особенности взаимоотношений детей в многодетной семье» [Текст] / Гаврилова А. [электронный ресурс]. - Режим доступа. - http://www.maam.ru/detskijsad/osobenosti-vzaimotnoshenii-detei-vmnogodetnoi-seme.html

15. Бакатаева А. А. Детско-родительские отношения в многодетных семьях [электронный ресурс]. - Режим доступа. - http://mybiblioteka.su/6-49330.html

16. Преподаватели Центра психологического образования. Баландина Людмила Леонидовна [Текст] / Пермский государственный национальный исследовательский университет. Региональный институт непрерывного образования. Центр психологического образования. [электронный ресурс]. Режим доступа. - http://psychology.psu.ru/prep_balandina.php

17. Антонов Анатолий Иванович (социолог) [текст] / Википедия. Свободная энциклопедия. [электронный ресурс]. - Режим доступа. https://ru.wikipedia.org/wiki/

\section{ТРЕНИНГ-ЭКСПЕРИМЕНТ ДЛЯ ЖЕНЩИН С СИНДРОМОМ ОТЛОЖЕННОЙ ЖИЗНИ Шубина О.В., Макаревская Ю.Э., Горошко В.Г.}

В наш динамичный век, когда кажется, что каждая минута на счету, и время, как песок, убегает сквозь пальцы, а все, что запланировали в жизни, мы катастрофически не успеваем сделать, существует параллельное явление, идущее вразрез со сверхзвуковыми скоростями сегодняшнего дня.

Каждый человек сознательно или неосознанно стремится к лучшему качеству жизни. Кто-то прилагает для этого больше усилий, принимая решения и действуя, не откладывая во временной ящик, волнующие его проблемы, ктото - меньше. А кто-то ждет, что вот совсем скоро произойдет нечто, и жизнь изменится, заиграет новыми красками, поддерживая внутренне желание начать все заново, в более качественном формате после того, как закончится временной период, мешающий жить по-настоящему сегодня.

Причин, мешающих жить, может быть множество - «вот перееду, тогда...», «вот, вырастут дети, муж бросит пить, найду новую работу, получу образование...». И человек не живет настоящей жизнью, а только подготовкой к ней, только создает условия для будущей жизни.

Первоначально идея «синдрома отложенной жизни» была разработана профессором Северного Международного университета, психологом Владимиром Петровичем Серкиным [10]. Его, как жителя Севера, заинтересовал вопрос об образе жизни северян - людей, живущих идеей переезда годами, и считающих, что настоящая, полная жизнь у них начнется 